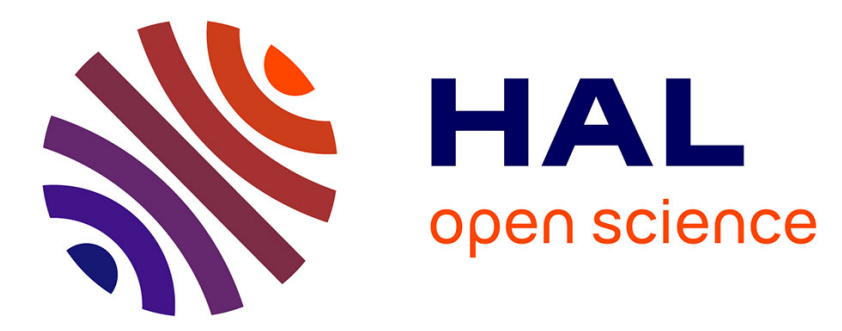

\title{
Mine water management in the former Gardanne lignite mine: towards sustainable uses of the mine aquifer
} Anne Dheilly, Bernard Brigati, Jean-Louis Nedellec, Marc Nicolas

\section{To cite this version:}

Anne Dheilly, Bernard Brigati, Jean-Louis Nedellec, Marc Nicolas. Mine water management in the former Gardanne lignite mine: towards sustainable uses of the mine aquifer. Mine Closure 2013, Sep 2013, Cornwall, United Kingdom. pp.135-148. hal-00849987

\section{HAL Id: hal-00849987 https: / hal-brgm.archives-ouvertes.fr/hal-00849987}

Submitted on 9 Oct 2013

HAL is a multi-disciplinary open access archive for the deposit and dissemination of scientific research documents, whether they are published or not. The documents may come from teaching and research institutions in France or abroad, or from public or private research centers.
L'archive ouverte pluridisciplinaire HAL, est destinée au dépôt et à la diffusion de documents scientifiques de niveau recherche, publiés ou non, émanant des établissements d'enseignement et de recherche français ou étrangers, des laboratoires publics ou privés. 


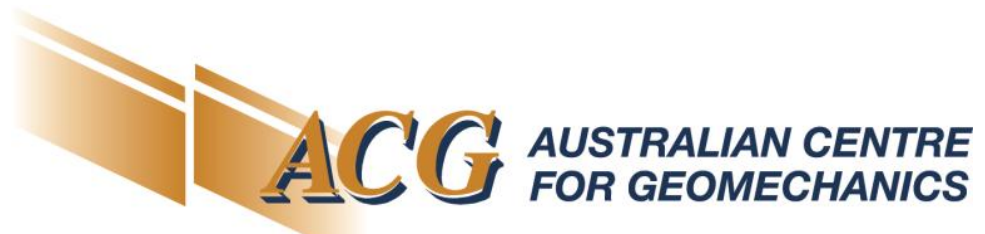

CSIRO | Curtin University I The University of Western Australia

Joint Venture

(C) Copyright 2013, Australian Centre for Geomechanics (ACG), The University of Western Australia. All rights reserved. No part of any ACG publication may be reproduced, stored or transmitted in any form without the prior written permission of the ACG.

The following paper appeared in Mine Closure 2013 proceedings published by the Australian Centre for Geomechanics.

Authors of the paper and third parties must obtain written permission from the ACG to publish all or part of this paper in future works. Suitable acknowledgement to the original source of publication must be included.

Note to authors: This version of your work is owned by the ACG.

This material may be used only on the following conditions:

- Copies of the material may be saved or printed for personal use only and must not be forwarded or sold to any third party.

- Commercial exploitation of the material is prohibited.

For further information:

Publication Sales Officer

Australian Centre for Geomechanics

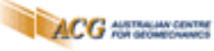

PO Box 3296 - BROADWAY

NEDLANDS WA 6009

AUSTRALIA

Mine Closure 2013

Ph: +61 864883300

sales-acg@uwa.edu.au

www.acg.uwa.edu.au

Proceedings of the Eighth International

Conference on Mine Closure

18-20 September 2013 | Cornwall | England
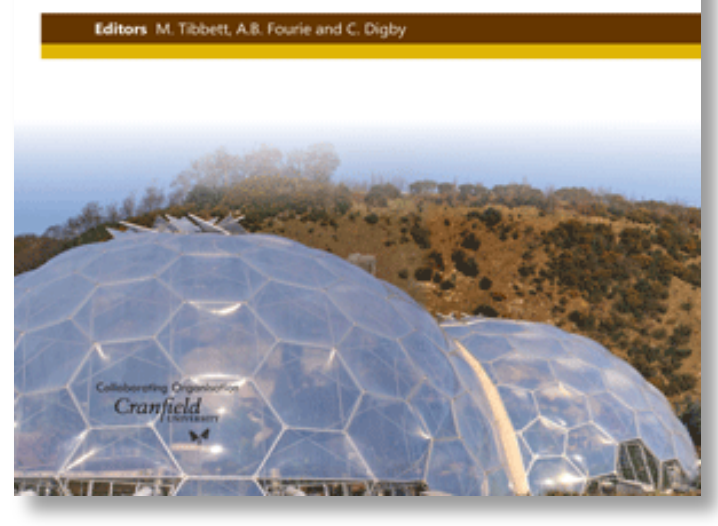


\title{
Mine water management in the former Gardanne lignite mine: towards sustainable uses of the mine aquifer
}

\author{
A. Dheilly Mine Safety and Risk Prevention Department, BRGM, France \\ B. Brigati Mine Safety and Risk Prevention Department, BRGM, France \\ J.L. Nedellec Mine Safety and Risk Prevention Department, BRGM, France \\ M. Nicolas Mine Safety and Risk Prevention Department, BRGM, France
}

\begin{abstract}
The Gardanne mine, extending $17 \mathrm{~km} \mathrm{E-W}$ and $10 \mathrm{~km} \mathrm{N-S} \mathrm{to} \mathrm{the} \mathrm{south} \mathrm{of} \mathrm{Aix-en-Provence} \mathrm{in} \mathrm{France,}$ operated seams of lignite interlayered with Fuvelian karstic limestone (Upper Cretaceous) from the seventeenth century up to 2003. The mine is in two main parts: one part lies in autochthonous terrain and the other part lies in a thrust sheet, the Lambeau Charrié.

To work in the dry, the water was pumped out and discharged into the Mediterranean (at Marseille) through a $14 \mathrm{~km}$ tunnel, the Galerie de la Mer, since 1905. The water came from two sources: the underlying Jurassic limestone aquifer, which has greater hydraulic head pressure than the mine and is in contact with it via the mine workings, and the rainwater infiltrating through the Fuvelian outcrops (autochthonous and thrust zones).
\end{abstract}

When mining ceased in 2003, the decision was made to let the water rise into the mine reservoir up to a certain level, at which point it would be maintained by pumping the excess water into the Gérard mineshaft on the Lambeau Charrié, to prevent mineralised mine waters from flooding into the natural environment. The water is drained first through the Galerie de la Mer, then through inclined boreholes to discharge diffusers at a depth of $30 \mathrm{~m}$ offshore from Marseille, to prevent the iron oxides from colouring the harbour water.

In 2006, BRGM (French Geological Survey) was mandated by the state to manage the former mining concession at Gardanne. By August 2010, the water level had risen from -1,100 to -14 meters above sea level (MASL), and pumping began at a rate of $600 \mathrm{~m}^{3} / \mathrm{h}$. This proved too slow to keep the water level under control. The rate was increased to $1,000 \mathrm{~m}^{3} / \mathrm{h}$ but water continued to rise (reaching -4 MASL in March 2013). Therefore, in 2012, the functional concept map of the mine reservoir was reviewed with the aid of a $3 D$ representation of the mine and hydrogeological simulations. These showed that the eastern, autochthonous, part of the mine, which had been worked by room-and-pillar methods with no backfilling, could be used to store a large volume of water under more hydraulic pressure than in the Gérard mineshaft. The study also showed that inflows of Jurassic water could be larger than anticipated when dewatering ceased near Gardanne. The interpretation of two years of pumping data concurred with the simulation results: changing the pumping facilities to increase their capacity therefore had to be considered.

In time, iron and sulphate concentrations are expected to drop, which would allow direct gravity discharge of the water into the port of Marseille. Potentially, the water could also be used as a low-enthalpy geothermal resource and/or a strategic drinking water resource.

\section{Introduction}

Since 2007, when the mining concession was relinquished, the Mine Safety and Risk Prevention Department (DPSM) of BRGM (French Geological Survey) has managed the Gardanne mine under a government mandate. One of the DPSM's main roles is to pump out the ferruginous mine water to prevent 
it from overflowing into the port of Marseille through a $14 \mathrm{~km}$ gallery to the sea (Galerie de la Mer), which dates back to 1905 and starts from the mine at +18 MASL (meters above sea level).

The task raises both technical and economic challenges. The short-term challenge is to redesign the facilities to increase the pumping capacities and prevent the reservoir from overflowing. Second, long-term maintenance of the facilities must be planned for to reduce the mineral content enough for the water to be discharged directly to the sea. The BRGM/DPSM therefore launched an in-depth analysis in 2010 to address these questions, a task that requires comprehensive understanding of the functioning of the mine aquifer. This was a lengthy analysis due to the complexity of the geological environment and of the mine itself. The geology of the Gardanne basin is complex, with a carbonated environment shaped by compressive tectonics and a lignite deposit in several layers, resulting in multiple coal faces. Mining took place over a long period (almost three centuries) and involved different successive techniques producing very different effects on the mine's long-term behaviour.

\section{Description of the Gardanne mine}

The Gardanne mine lies to the south-east of Aix-en-Provence (France) (see Figure 1). It extends for $17 \mathrm{~km}$ from east to west and $10 \mathrm{~km}$ from north to south. Several lignite seams (0.8-3.5 m in thickness) are interlayered with Fuvelian karstic limestone (Upper Cretaceous) and were mined from the seventeenth century up to 2003. By the time mining ceased in August 2003, about 1.5 billion tonnes had been extracted altogether.

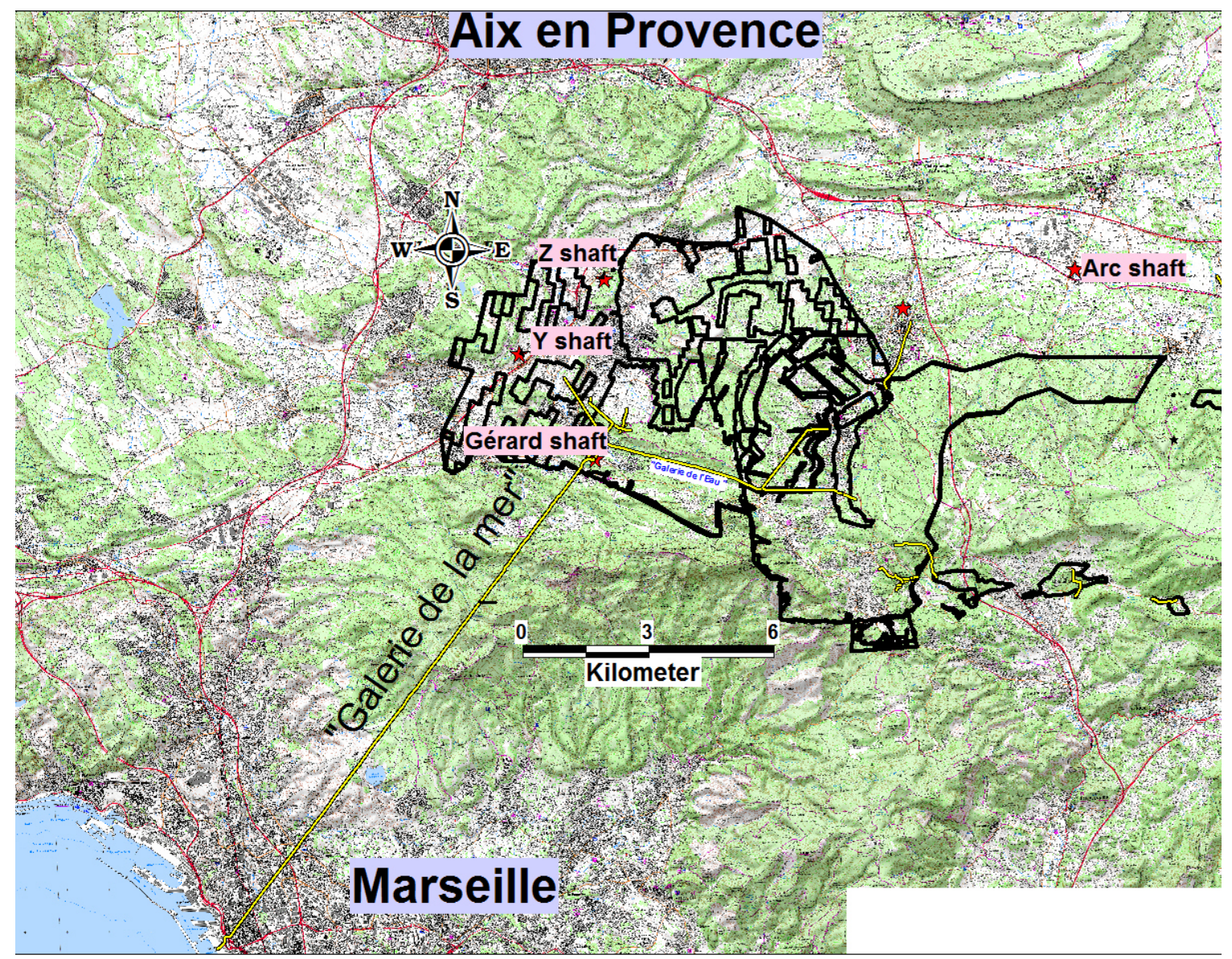

Figure 1 Location of the Gardanne mine (red line) between Aix-en-Provence and Marseille, showing the main mineshafts monitored since mining ceased

The mine is in two main parts (see Figures 2 and 3): 
- One part lies in autochthonous terrain, where the deepest lignite seam, Grande Mine, outcrops towards the east (at $+320 \mathrm{MASL}$ ) and reaches a depth of 1,400 $\mathrm{m}$ in the western part of the mine $(-1,100 \mathrm{MASL})$ below a tertiary overburden.

- The other part lies in a thrust sheet, the Lambeau Charrié, perpendicular to the autochthonous (geological layer found at its site of formation or deposition) terrain and in the southwestern part of the mine, where the Grande Mine seam runs from the outcrop at +290 MASL to -230 MASL below a more recent overburden.

\section{Four lignite layers inside karstified limestone of fuvelien formation (upper cretaceous)}

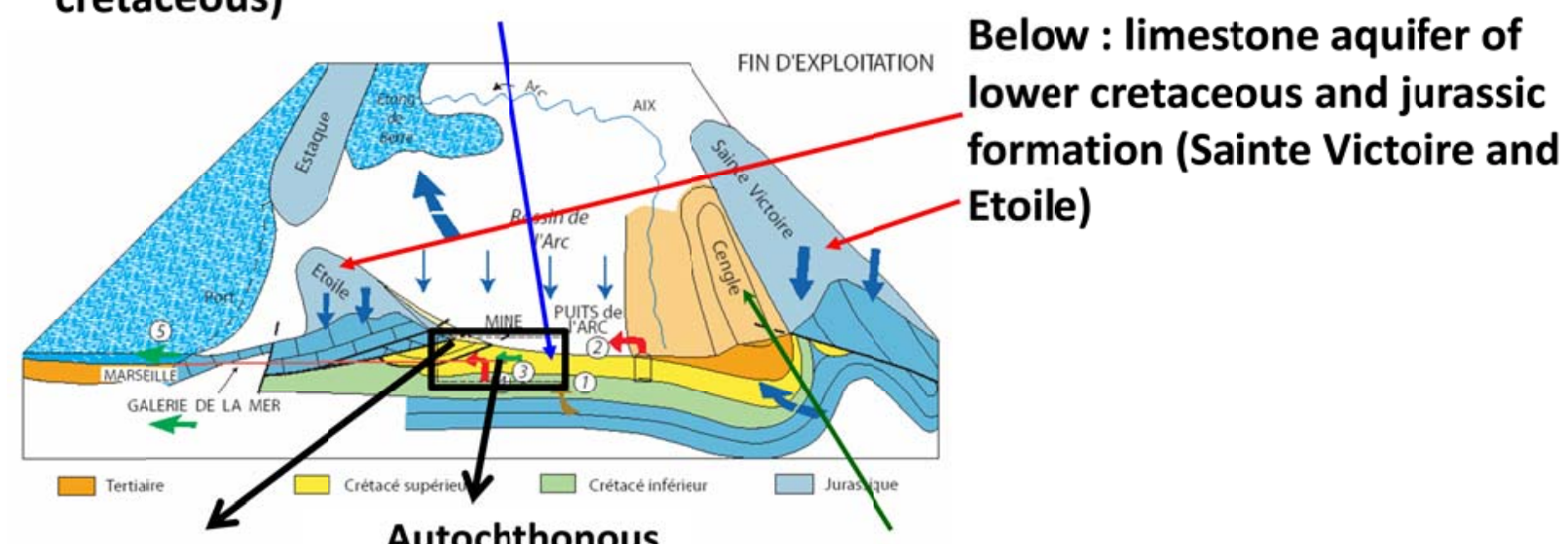

Lambeau Charrié

Autochthonous area

Above: latter series: clay and limestone

Figure 2 The Gardanne mine in its geological and hydrogeological context

Four lignite seams were mined: Grande Mine (in green), the deepest and most intensively mined as it is the thickest at 2.5-3.5 m; Mauvaise Mine (in blue); 4 Pans (in orange); and Gros Rocher (in pink). The latter three seams have an average thickness of around $0.8 \mathrm{~m}$ and were mainly worked in the Lambeau Charrié and the southern and eastern parts of the autochthonous mine area.

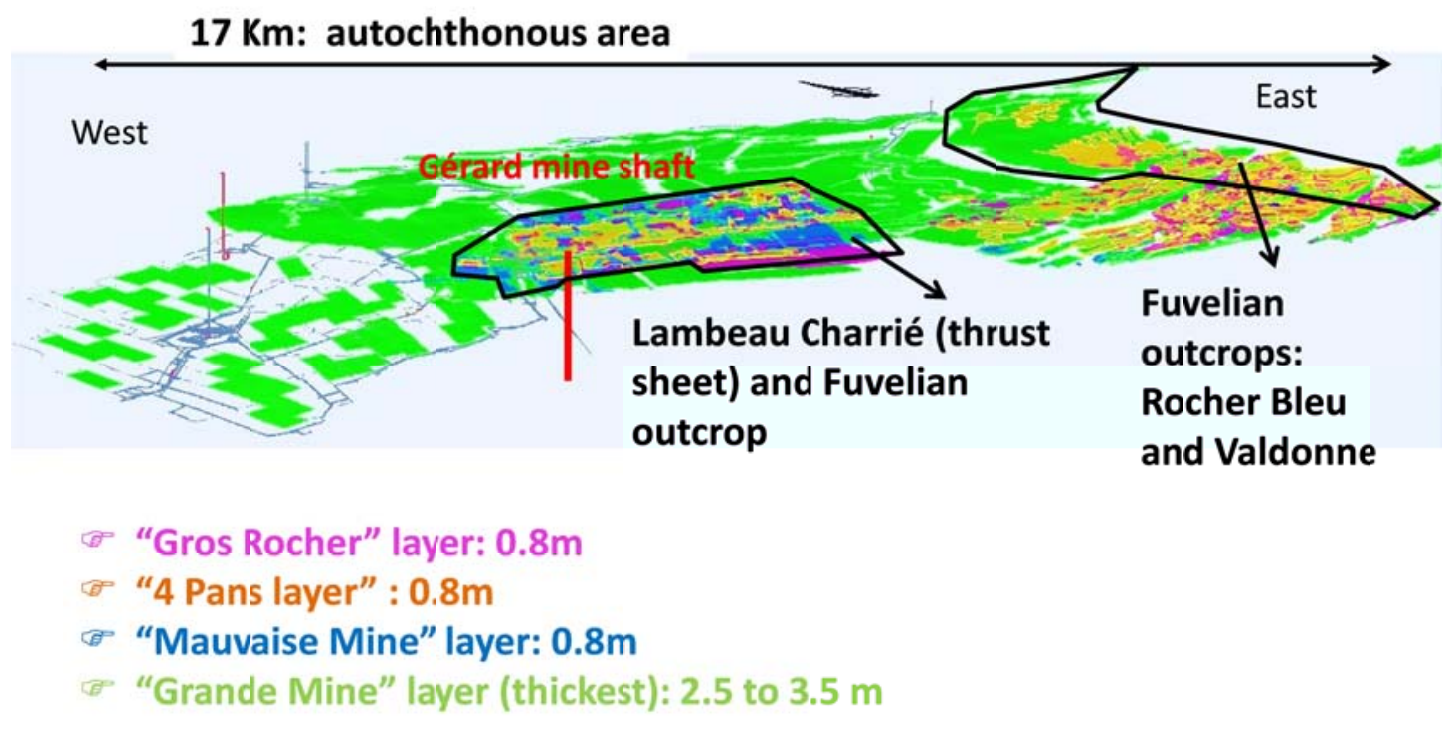

Figure 3 Location and thickness of the lignite seams mined in the autochthonous terrain and in the Lambeau Charrié 


\section{$3 \quad$ Changing techniques and extension of mine workings over time}

Coal (lignite) mining at Gardanne began in the seventeenth century. Mining methods changed a great deal, partly for technical reasons (mechanisation and electrification) and partly as the mine workings extended into deeper layers of the deposit, to the east in the autochthonous part and to the south in the Lambeau Charrié. The methods used may be outlined as follows (see Figure 4):

- Early haphazard workings $(<1850)$ close to the outcrops (eastern part of the mine and along the Lambeau Charrié).

- Successively abandoned room-and-pillar workings (<1976) between +250 and $-120 \mathrm{MASL}$, to the east and along the Lambeau Charrié; these workings were backfilled along the Lambeau Charrié but not in the eastern part of the autochthonous area.

- Block caving caved long wall (>1930) between -120 and -1,100 MASL (in the middle and western parts of the mine).

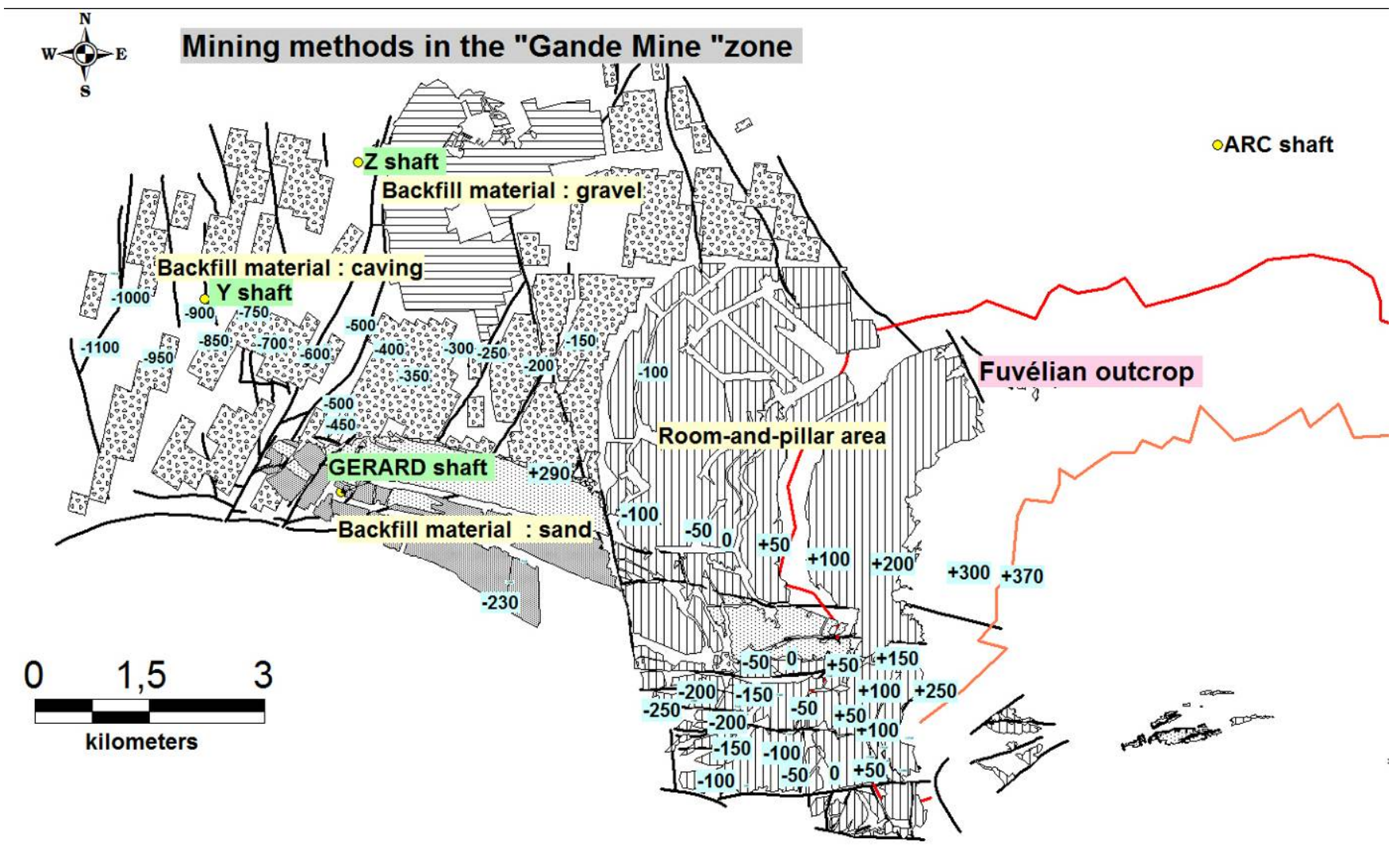

Figure 4 Mining and backfilling methods along the "Grande Mine" seam

\section{$4 \quad$ Sources of the water pumped out during mining}

To maintain dry working conditions, at the beginning of the exploitation the mine waters were drained using galleries, then pumped out. After 1905, the water was channelled towards the Mediterranean through the $14 \mathrm{~km}$ Galerie de la Mer and discharged into the port of Marseille. At the time, the mineral content was low, as the water was only in contact with the mine reservoir for a short time.

The water came from two sources:

- The underlying Jurassic limestone aquifer, which was under greater hydraulic pressure than in the mine and in contact with it when mining operations were extended to the northeast: the flow rate was relatively constant at around 250 to $300 \mathrm{~m}^{3} / \mathrm{h}$. 
- rainwater infiltrating through the Fuvelian outcrops in the autochthonous zone and the Lambeau Charrié: the flow rate in this case varied widely from 0 to over $1,000 \mathrm{~m}^{3} / \mathrm{h}$, following the rainfall pattern in the Mediterranean region.

The average pumping from these two sources was $800 \mathrm{~m}^{3} / \mathrm{h}$.

\section{$5 \quad$ Post-mining water management}

When mining ceased in 2003, the decision was made to let the water rise into the mine reservoir up to a certain level (see Figure 5), at which point it would be maintained by pumping the excess water into the Gérard mineshaft on the Lambeau Charrié, to prevent mineralised mine water from overflowing (iron: 40 $\mathrm{mg} / \mathrm{l}$, sulphates: $2,300 \mathrm{mg} / \mathrm{l})$. The water is evacuated first through the Galerie de la Mer, then through inclined boreholes to discharge diffusers at a depth of $30 \mathrm{~m}$ offshore from Marseille, to prevent the iron oxides from colouring the harbour water.

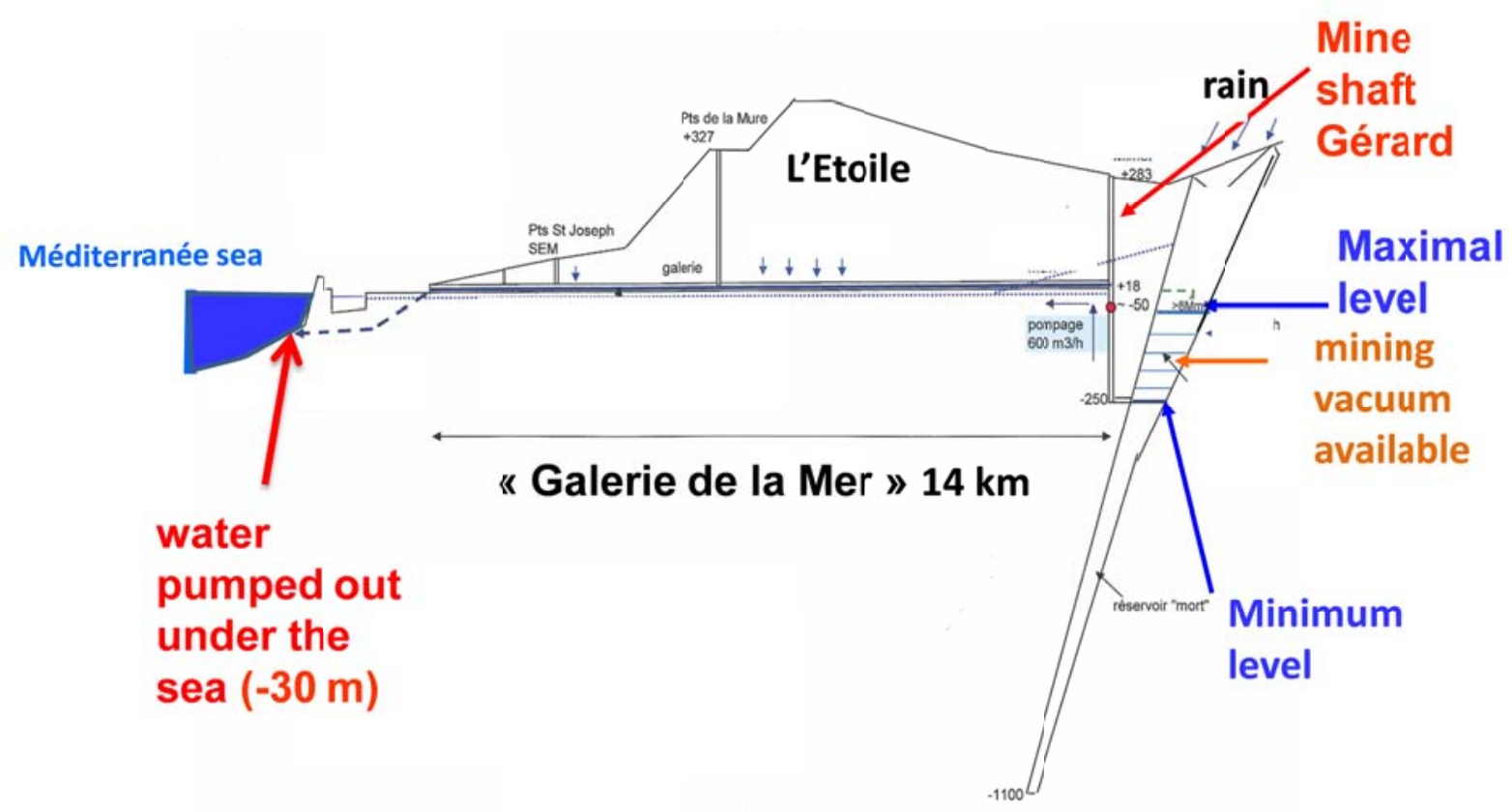

Figure 5 Diagram of post-mining management of the mine water reservoir

To control the water level in the mine reservoir and maintain the same water level across the entire mine, the pumping rate was initially set at $600 \mathrm{~m}^{3} / \mathrm{h}$. The rainwater infiltrating through the Fuvelian outcrops to the east would drain away through another gallery, the Galerie des Eaux, which would discharge it into the natural environment as its mineral content would be low (only in brief contact with the mine reservoir). The room-and-pillar workings with no backfilling would thus remain flooded.

\section{$6 \quad$ Post-mine dewatering: problems encountered}

From the time when mining ceased in 2003 and the start of dewatering in 2010, the water level in the mine reservoir rose from $-1,100 \mathrm{~m}$ to $-14 \mathrm{MASL}$, entirely flooding $15-45$ million $\mathrm{m}^{3}$ of mine cavities. On 4 August 2010, pumping began in the Gérard mineshaft at $600 \mathrm{~m}^{3} / \mathrm{h}$. Figure 6 shows changes in the water level (blue dots and scale in MASL on the left) according to the pumping rate (red dots, whose figures on the right scale (in $\mathrm{m} 3 / \mathrm{h}$ ) must be multiplied by 10 ), rainfall (green line) and effective rainfall (part of rainwater available for infiltration or runoff) (purple line) in Aix-en-Provence (data from Météo-France) shown in millimetres on the right.

Contrary to expectations, the water level continued to rise in the mineshaft despite pumping at a rate of $600 \mathrm{~m}^{3} / \mathrm{h}$, which soon had to be increased to $800 \mathrm{~m}^{3} / \mathrm{h}$. For a short time (from 18 Sept to 21 Oct 2010), this 
kept the water level at around -11.20 MASL. The water level then began to drop to $-12.53 \mathrm{MASL}$ (11 Dec 2010). However, this was cancelled out by effective winter rainfall that raised the level over several months to -4.80 MASL (on $18 \mathrm{Apr}$ 2011). The level dropped again when effective rainfall ceased, but rose once more whenever rainfall became effective. When dewatering ceased for pump maintenance work from 12 Jun to $16 \mathrm{Jul} 2012$, the water level rose to $-1.80 \mathrm{MASL}$, and it dropped again as soon as the pumps were restarted. After heavy rainfall in the first three months of 2013 , the level rose yet again to reach -4.36 MASL at the end of March. The water did not drop back to its initial level of -14 MASL at any time during this entire monitoring period.

The mine reservoir was not reacting as expected, and the analysis of two years of pumping data shows that the existing pumps do not have the capacity to control the water level in the Gérard mineshaft.

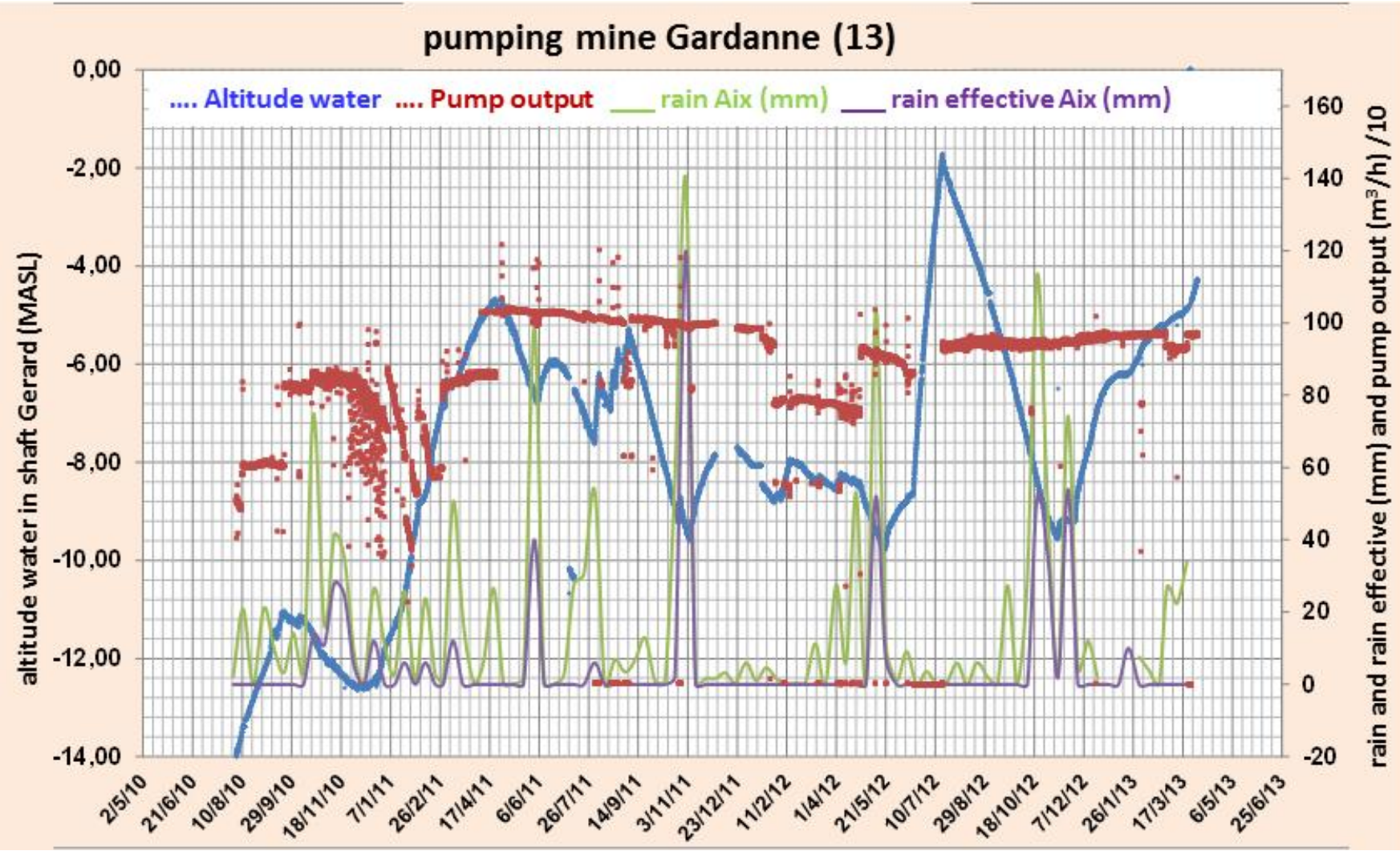

Figure 6 Changes in the water level in the Gérard mineshaft according to pumping rate, rainfall and effective rainfall in Aix-en-Provence, from August 2010 to the end of March 2013

\section{$7 \quad$ Understanding of the water behaviour in the mine: methods implemented in 2012}

Several approaches were implemented in 2012 to help understand how the water functions in this subterranean mine environment:

- 3D modelling of the geology in the mine region.

- $3 D$ representation of the mine incorporating the geological context.

- Interpretation of the dewatering curve for the Gérard mineshaft from 2010 to 2011.

- Interpretation of the water level contour line from 2004 to 2012 with GARDEMUL software (GARDEMUL is an application that analyses inflow and outflow in a hydrogeological system based on GARDENIA. It was developed by BRGM to impose more constraints on the system). 
The first two approaches (mainly geometric to date) aim to produce a better understanding of the mine within its environment. They allowed the interactions to be visualised between the different mined areas and between the mine and its geological context and led to the hypotheses and justifications put forward for the analyses of the dewatering curve and subsequent simulations. These investigations produced a better assessment of the flow regimes at work in the mine reservoir to support the design of new dewatering facilities.

\subsection{Regional geology model in three dimensions}

This model was built up with the BRGM-Intrepid Geophysics 3DGeoModeller (Stephan-Perrey et al., 2011).

An important feature of the 3D model is that the descriptions of deep formations take all the data supplied (wells, maps, sections) into account. The model has to represent the geometry of these formations as ceilings or walls as well as their inter-relationships based on the regional geological structure (normal or reverse faults, folds, thrust zones, diapiric zones) and the relationships between different accidents and between faults and formations.

To build up the 3D geological model of the Gardanne mining basin at the regional scale, all the available data were used: core sample sections, $1 / 50,000$ and 1/250,000 geological maps, 2D sections from the literature and seismic profiles.

The network of faults was modelled taking account of the model scale and the scale of accidents according to their slip, links with series, relationship with other accidents and extent.

Each formation was then modelled in turn, checking that all input data were taken into account. All source data (core sections, boundaries of outcropping formations, etc.) are incorporated in the final 3D model (see Figure 7) to give a coherent picture of the geometry of the deep subsurface formations.

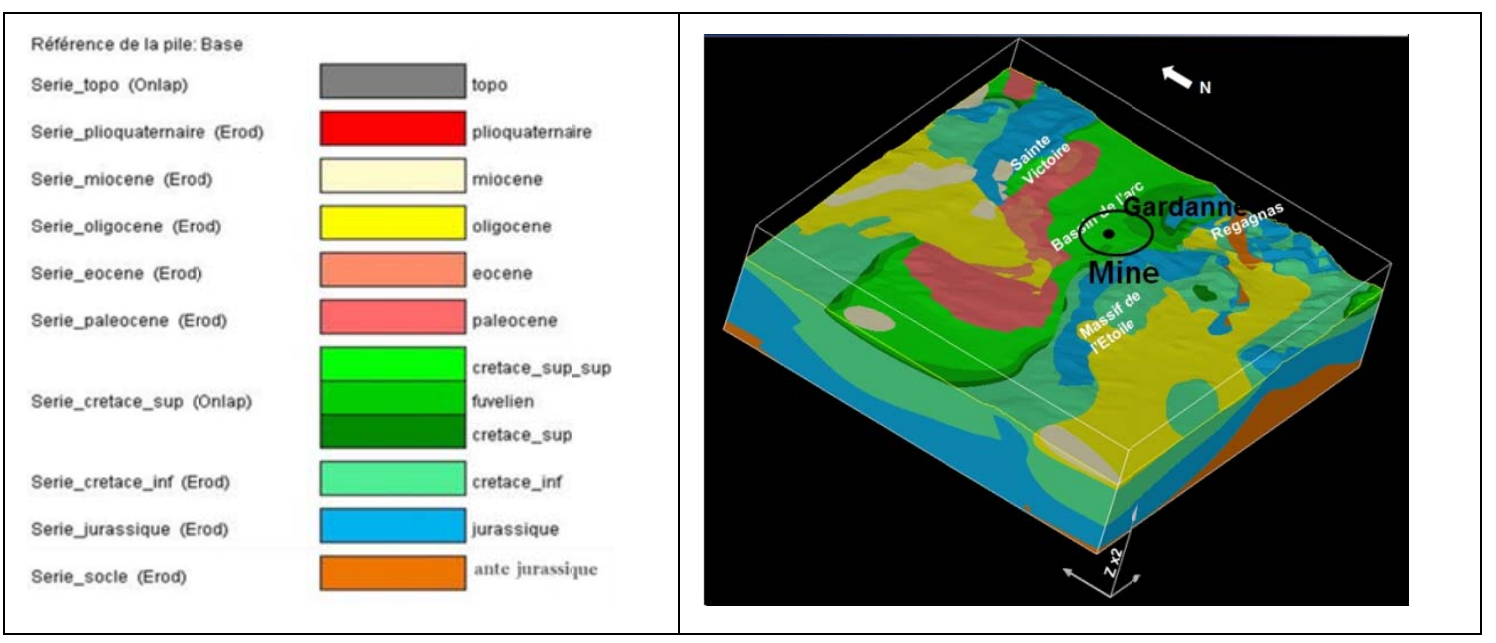

Figure 7 Stratigraphy and geology of the Gardanne region

The Gardanne mine is set in the broader geological context of the Arc basin. This is a clearly marked synclinal basin (see Figure 8) that may be defined as a multilayer aquifer, with each layer corresponding to an individual reservoir that is more or less isolated from the others. This structure may be attributed to the Pyrenean-Provençal phase that preceded the Alpine events and caused compression along a north-south axis. The axis of the syncline therefore runs east to west overall. 


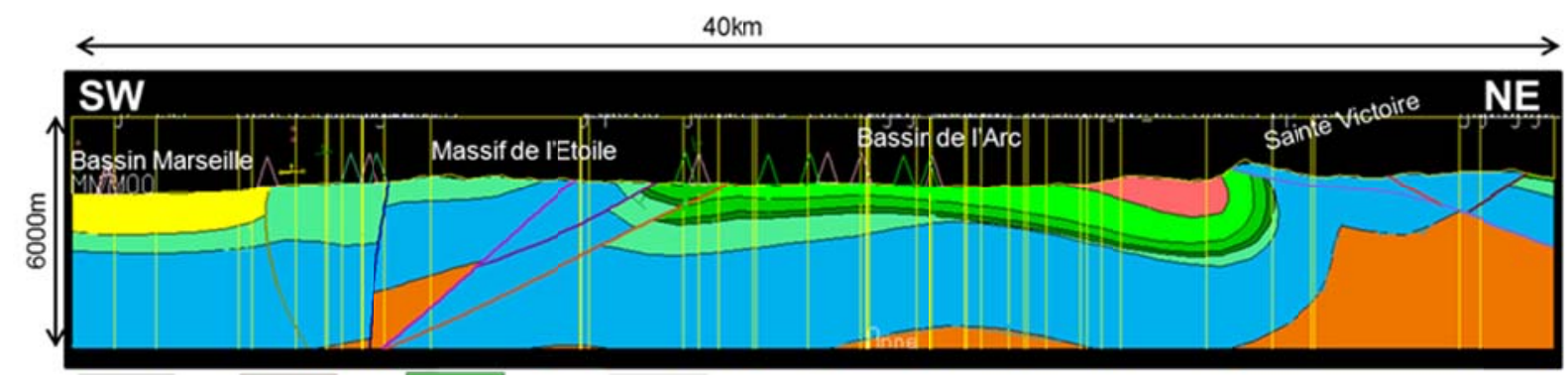

Figure 8 SW-NE section from the port of Marseille to the Sainte-Victoire range

It is limited to the north and south by generally complex folded structures and fault and thrust accidents:

- The Saint Victoire range to the north, with complex thrusts and mainly southward vergence formed by the Alpine orogeny, peaking at an altitude of $1,000 \mathrm{~m}$.

- To the south, the syncline is encircled by the Etoile and Regagnas ranges of Cretaceous and/or Jurassic autochthonous or allochthonous limestone.

The syncline is traversed by brittle faults lying mainly east to west, which were formed or reformed by the Alpine orogeny and produced a complex and compartmentalised whole.

\subsection{Representation of mine in three dimensions}

The mine was represented in 3D by running Autodesk Autocad ${ }^{\circledR}$ with sometimes very early layout plans from mine archives. With the 3D representation, each mine sector and the galleries connecting them to each other and to the Gérard landing station could be accurately located.

The 3D representation of the mine was then reintroduced into the 3D model of the regional geology to support the next analysis phase. The layers of lignite of Lambeau Charrie are independent of the autochthonous mine. The two parts of mine are interconnected by shafts and galleries (see Figure 9). 


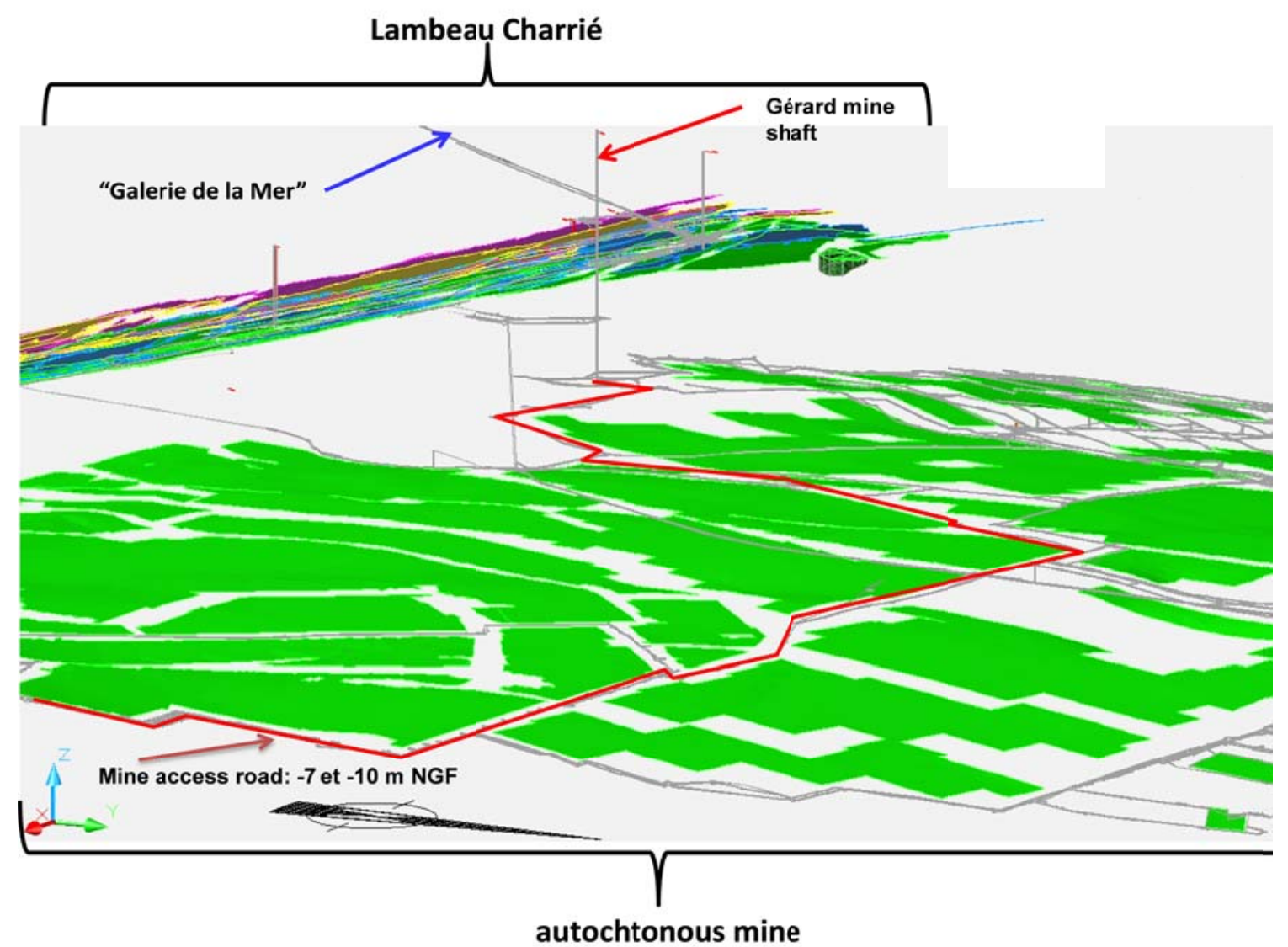

Figure 93 v view of the mine produced with Autocad

\subsection{Interpretation of pumping data for one year}

A report was produced after one year of dewatering (Dheilly, 2011). The reference effective rainfall was calculated by Météo France with a usable ground reserve of $50 \mathrm{~mm}$.

The baseline assumption was that the mine would behave like a reservoir with an estimated cavity volume per meter of about 70,000 $\mathrm{m}^{3}$ for the -100 to $0 \mathrm{~m}$ MASL section. This was the "mine-based approach" applied by the CESAME engineering consultancy (CESAME, 2002), which conducted the initial studies.

\subsubsection{Assessment of water volumes from infiltrating rainfall}

Only one effective rainfall event, which occurred in June 2011 during a period of stable pumping rates, could be used to estimate rainwater volumes.

All the water volumes pumped out during the period of water level instability (from the start of flooding until the water dropped back to its initial level before the rain, from 3 to 18 Jun 2011) were considered as produced by effective rainfall infiltration. The constant $800 \mathrm{~m}^{3} / \mathrm{h}$ inflow to the shaft was used solely to maintain a constant water level. Next, the percentage of effective rainfall infiltration (for Mimet, a town lying very close to the mine) in this volume of water was applied to the surface area of all the outcrops (28 $\mathrm{km}^{2}$ ). This number was estimated at $77 \%$. This high rate of effective rainfall is due to the infiltration through karstified limestone outcrops (see Table 1).

Incoming volumes in the mine

77\% infiltration of effective rainfall at Mimet over the watersheds 


\begin{tabular}{cccccccc}
\hline $\begin{array}{c}\text { Effective } \\
\text { rainfall in } \\
\text { Aix }(\mathrm{m})\end{array}$ & $\begin{array}{c}\text { Effective } \\
\text { rainfall in } \\
\text { Mimet } \\
(\mathrm{m})\end{array}$ & $\begin{array}{c}\text { \% of } \\
\text { infiltration }\end{array}$ & $\begin{array}{c}\text { Infiltration } \\
(\mathrm{m})\end{array}$ & $\begin{array}{c}\text { Effective } \\
\text { rainfall } \\
\text { périod }\end{array}$ & $\begin{array}{c}\text { infiltration } \\
\text { area }\left(\mathrm{km}^{2}\right)\end{array}$ & $\begin{array}{c}\text { Infiltrated } \\
\text { volume on } \\
\text { watersheds } \\
\left(\mathrm{m}^{3}\right)\end{array}$ & $\begin{array}{c}\text { Infiltrated } \\
\text { volume on } \\
\text { watersheds } \\
(\mathrm{m} 3 / \mathrm{h})\end{array}$ \\
\hline 0.04 & 0.051 & 77 & 0.039 & $\begin{array}{c}03 / 06 \mathrm{au} \\
17 / 07 / 2011\end{array}$ & 28 & $1,095,248$ & 1,014 \\
\hline
\end{tabular}

Table 1 Estimation of water volumes resulting from $77 \%$ infiltration of effective rainfall (Mimet)

\subsubsection{Results for one year}

The estimated effective autumn and winter rainfall infiltration calculated as described above was then used to calculate the figure for the entire year by adding the constant $800 \mathrm{~m}^{3} / \mathrm{h}$ inflow from the Jurassic aquifer and the eastern part of the mine (see Table 2).

\begin{tabular}{|c|c|c|c|c|c|c|c|c|c|c|c|}
\hline \multicolumn{3}{|c|}{$\begin{array}{l}\text { Volumes from fuvélian and } \\
\text { Jurassic aquifers }\end{array}$} & \multicolumn{3}{|c|}{$\begin{array}{l}\text { Volume from effective rainfall } \\
\text { infiltration }(\mathrm{m} 3)\end{array}$} & \multicolumn{2}{|c|}{$\begin{array}{c}\text { Total volumes } \\
\text { pumped out to } \\
\text { stay at the same } \\
\text { level }\end{array}$} & \multicolumn{2}{|c|}{$\begin{array}{l}\text { total volume } \\
\text { really pumped } \\
\text { out }\end{array}$} & \multicolumn{2}{|c|}{$\begin{array}{c}\text { difference } \\
\text { volume (m3) }\end{array}$} \\
\hline $\begin{array}{l}\text { Outflo } \\
\qquad \begin{array}{l}\mathrm{w} \\
\left(\mathrm{m}^{3} / \mathrm{h}\right)\end{array}\end{array}$ & $\begin{array}{l}\text { numbe } \\
r \text { of } \\
\text { days }\end{array}$ & $\begin{array}{l}\text { subtotal } \\
\left(\mathrm{m}^{3}\right)\end{array}$ & winter & June & subtotal & $\mathrm{m}^{3}$ & $\mathrm{~m}^{3} / \mathrm{h}$ & $\mathrm{m}^{3}$ & $\mathrm{~m}^{3} / \mathrm{h}$ & $\mathrm{m}^{3}$ & $\mathrm{~m}^{3} / \mathrm{h}$ \\
\hline 800 & 365 & $\begin{array}{c}7,008,00 \\
0\end{array}$ & $\begin{array}{c}3,258,36 \\
3\end{array}$ & $\begin{array}{c}1,095,24 \\
8\end{array}$ & $\begin{array}{c}4,353,61 \\
1\end{array}$ & $\begin{array}{c}11,361,61 \\
1\end{array}$ & $\begin{array}{c}1,31 \\
5\end{array}$ & $\begin{array}{c}7,034,00 \\
0\end{array}$ & $\begin{array}{c}81 \\
4\end{array}$ & $\begin{array}{c}4,327,61 \\
1\end{array}$ & $\begin{array}{c}49 \\
4\end{array}$ \\
\hline
\end{tabular}

\section{Table 2 Annual water volumes pumped from the mine reservoir based on the above} assumptions

To keep the water at its initial level of -14 MASL before pumping began, an average pumping rate of $1,300 \mathrm{~m}^{3} / \mathrm{h}(800+494)$ would have been required. The annual dewatering deficit was at least $4.3 \cdot 10^{6} \mathrm{~m}^{3}-$ that is, $495 \mathrm{~m}^{3} / \mathrm{h}$ on average, which caused a $6.43 \mathrm{~m}$ rise in the water level.

\subsubsection{The new concept map}

The water pumped out appears to have two sources:

The first source is the volume produced by the continuous and simultaneous inflow from the deep Jurassic aquifer and the eastern part of the flooded mine, where the water is under more pressure than in the Lambeau Charrié. Water from the two sources flows continuously into the Gérard mineshaft at about 800 $\mathrm{m}^{3} / \mathrm{h}$. These rates have increased because:

- A shaft near the mine, Arc shaft, pumping out Jurassic aquifer between 1500 and $2000 \mathrm{m3} / \mathrm{h}$ has been arrested since 2003.

- Stocks of water formed in the room-and-pillar workings of the eastern part of the mine during the shutdown period pumping from 2003 to 2010.

Water level measurements in workings crossing the mine from the eastern outcrops suggest the storage of a water volume in the eastern part of the mine (see Figure 10). The water level is at +205 MASL at Fuveau (OS), at +271 MASL at the Champisse measurement point and at +265 MASL at the Lecas measurement point. This flooded part of the eastern part of the mine is under more hydraulic pressure than the water in the Gérard mineshaft at around -10 MASL. 


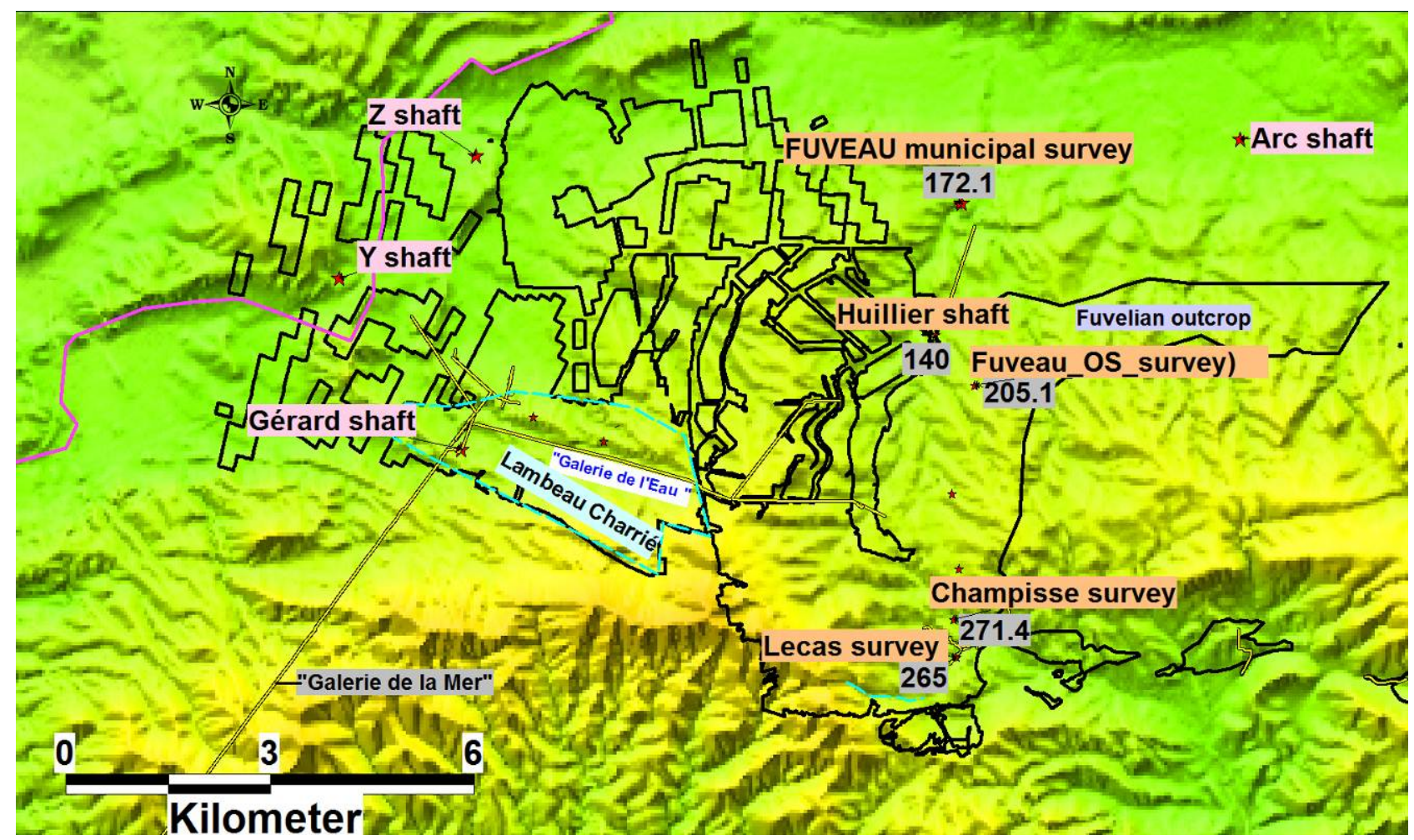

Figure 10 Mine reservoir water levels and their location in the mine workings on the Fuvelian outcrops to the east

The second source of the water is the variable volume generated by effective rainfall infiltration over a total surface area of $28 \mathrm{~km}^{2}$ consisting of the Fuvelian outcrops and part of the Bégudien, Lambeau Charrié and eastern part of the autochthonous mine area.

Figure 11, although fairly complex, summarises the hypotheses described above. The mine is compartmentalised, with the aquiferous eastern part of the autochthonous mine area under more pressure than the less aquiferous western part and the Lambeau Charrié. 


\section{Pumping in the Shaft Gerard from august 2010}

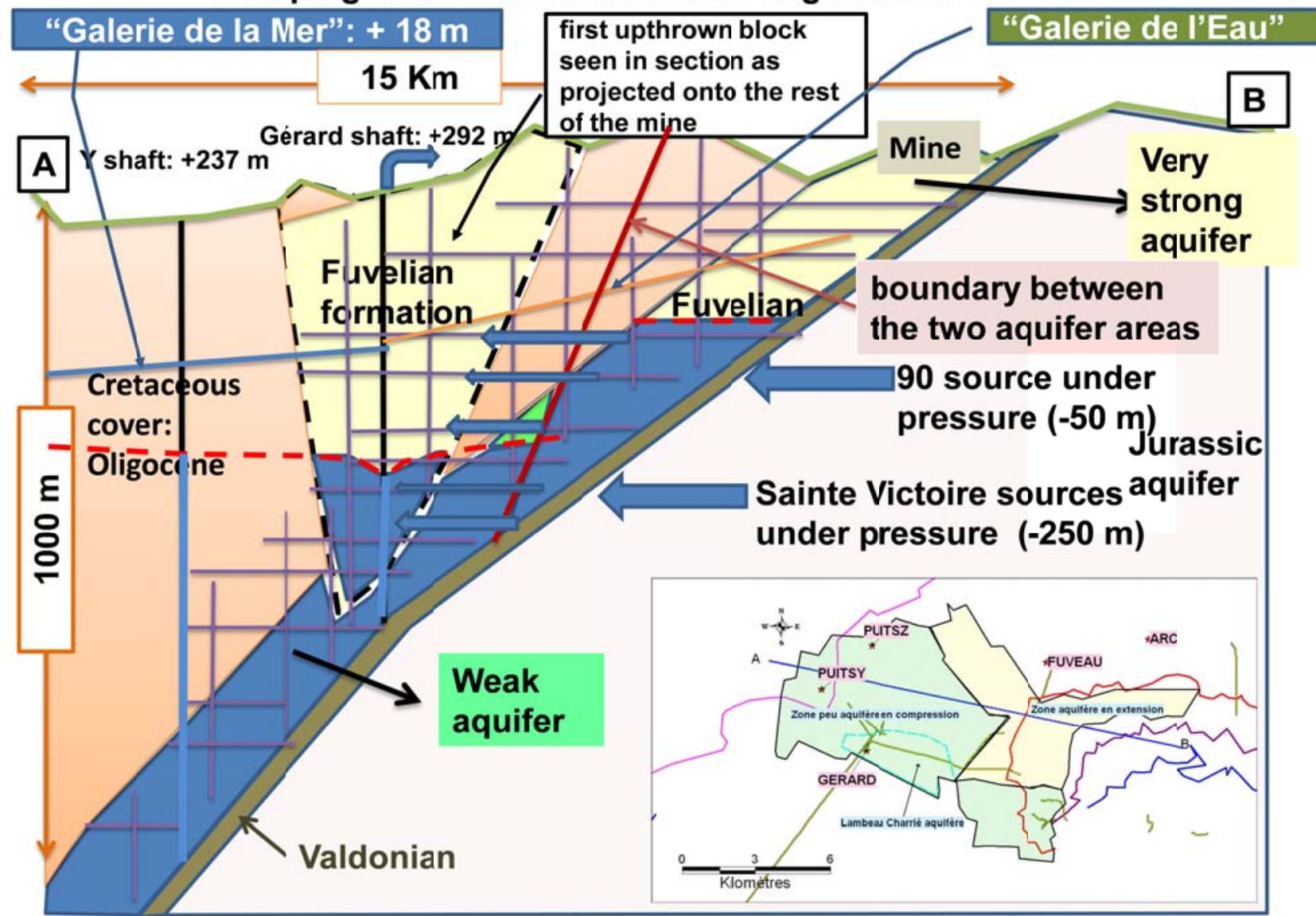

Figure $11 \quad$ Functional concept map of the mine reservoir after mining came to an end

Figure 12 is a simplified concept map of the mine reservoir after mining came to an end.

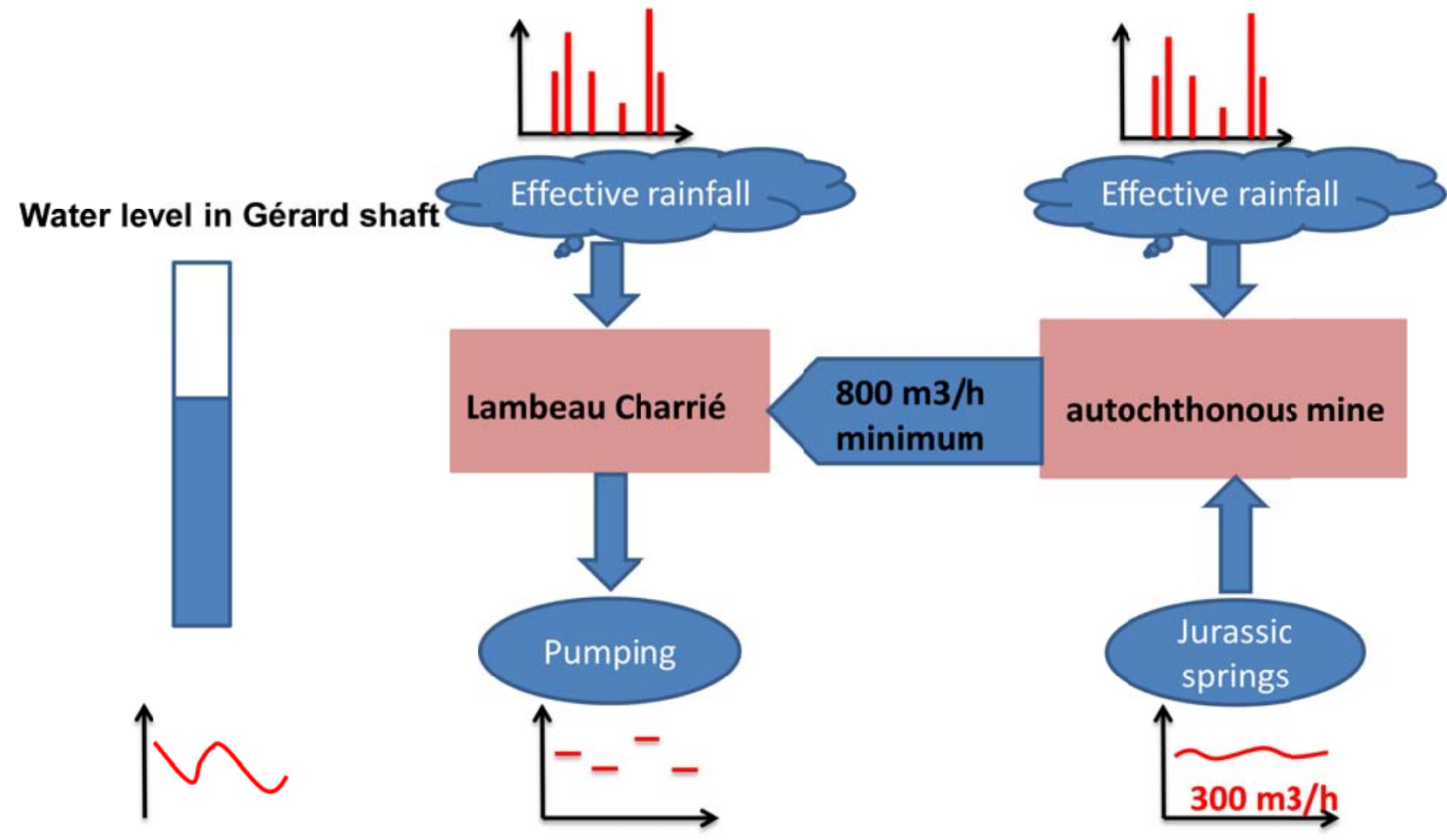


Figure 12 Simplified functional concept map of the mine reservoir after mining came to an end

\subsubsection{Estimation of required pumping rates}

Based on the above estimations, the pumping rates required to keep the water at a constant level vary from $806 \mathrm{~m}^{3} / \mathrm{h}$ to $1,900 \mathrm{~m}^{3} / \mathrm{h}$ depending on effective rainfall, given that water from the eastern part of the autochthonous mine area and the Jurassic aquifer is flowing continuously into the Gérard mineshaft at a rate of $800 \mathrm{~m}^{3} / \mathrm{h}$.

\subsection{Interpretation with the GARDEMUL application}

The GARDEMUL application was tested (Thiéry, 2012) with the entire time series for water levels since the mine ceased operations in 2003 and with water level variations after pumping began (2010-12).

Effective rainfall was determined by running GARDEMUL with 10-day or daily rainfall data for Aix-enProvence and Mimet purchased from Météo France. Potential 10-day evapotranspiration at Aix is very regular, with a minimum of $5 \mathrm{~mm} / 10$ days in winter and a maximum of $60-70 \mathrm{~mm} / 10$ days (or $6-6.5$ $\mathrm{mm} /$ day) in July or August.

\subsubsection{GARDEMUL modelling of the reconstructed water level in mineshaft $Y$ at 10-day intervals, 2004-12}

Input data for the model:

- 10-day rainfall and potential evapotranspiration at Aix-en-Provence, 2003-12.

- 10-day pumping rates over the same period.

- A constant "water table recharge" rate throughout the period simulated.

The correlation coefficient between the series observed (in red) and the simulated series (in blue) is greater than 0.999 (see Figure 13).

\section{GARDEMUL simulation based on pumping data at ten-day intervals}

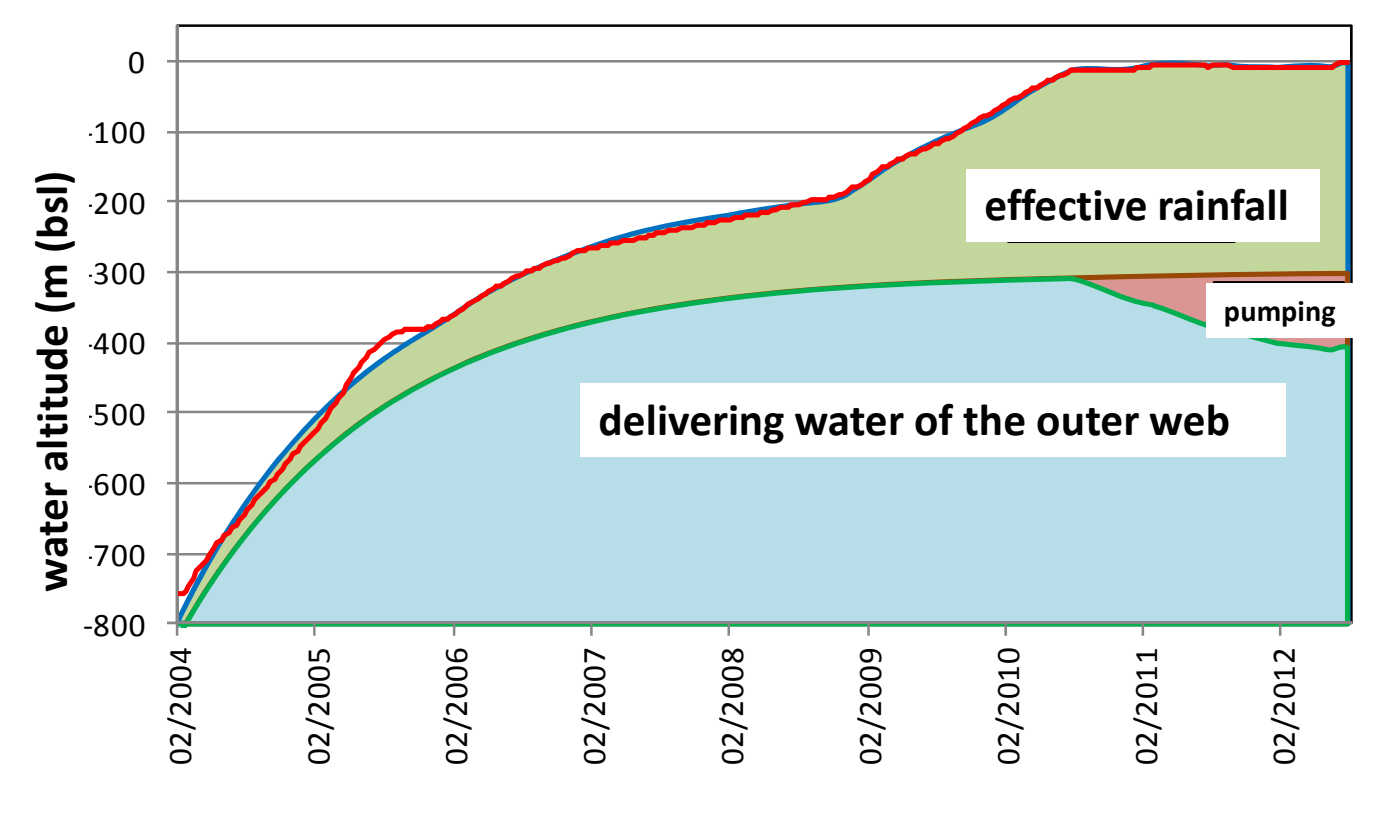

Figure 13 The GARDEMUL model: continuous simulation at 10-day intervals from February 2004 to July 2012 (red curve: observed level). 
The modelling exercise produced a breakdown of the influence of each parameter on the observed water level:

- Significant influence of water table recharge from 2004 until it levels out in 2010 (low hydraulic head differential).

- The influence of effective rainfall is low at the start of the time series (2004), then very significant from 2009 to 2012 following the large quantity of rainfall. The different slopes of the curve for 2004-10 are mainly due to variations in effective rainfall during the different periods.

- From August 2010, dewatering rates are compensated by inflows from effective rainfall as water table recharge becomes negligible; the contour line shows the water table levelling out at -10 to 4 MASL.

\subsubsection{GARDEMUL model results with daily pumping data from August 2010 to July 2012}

As the influence of 'water table recharge' was negligible when pumping began, a detailed modelling exercise at one-day intervals was performed with just two components (see Figure 14):

- average daily rainfall at Aix-en-Provence and Mimet and pseudo-daily evapotranspiration for Aix.

- daily pumping rates in the Gérard mineshaft.

The calibration coefficient is 0.993 .

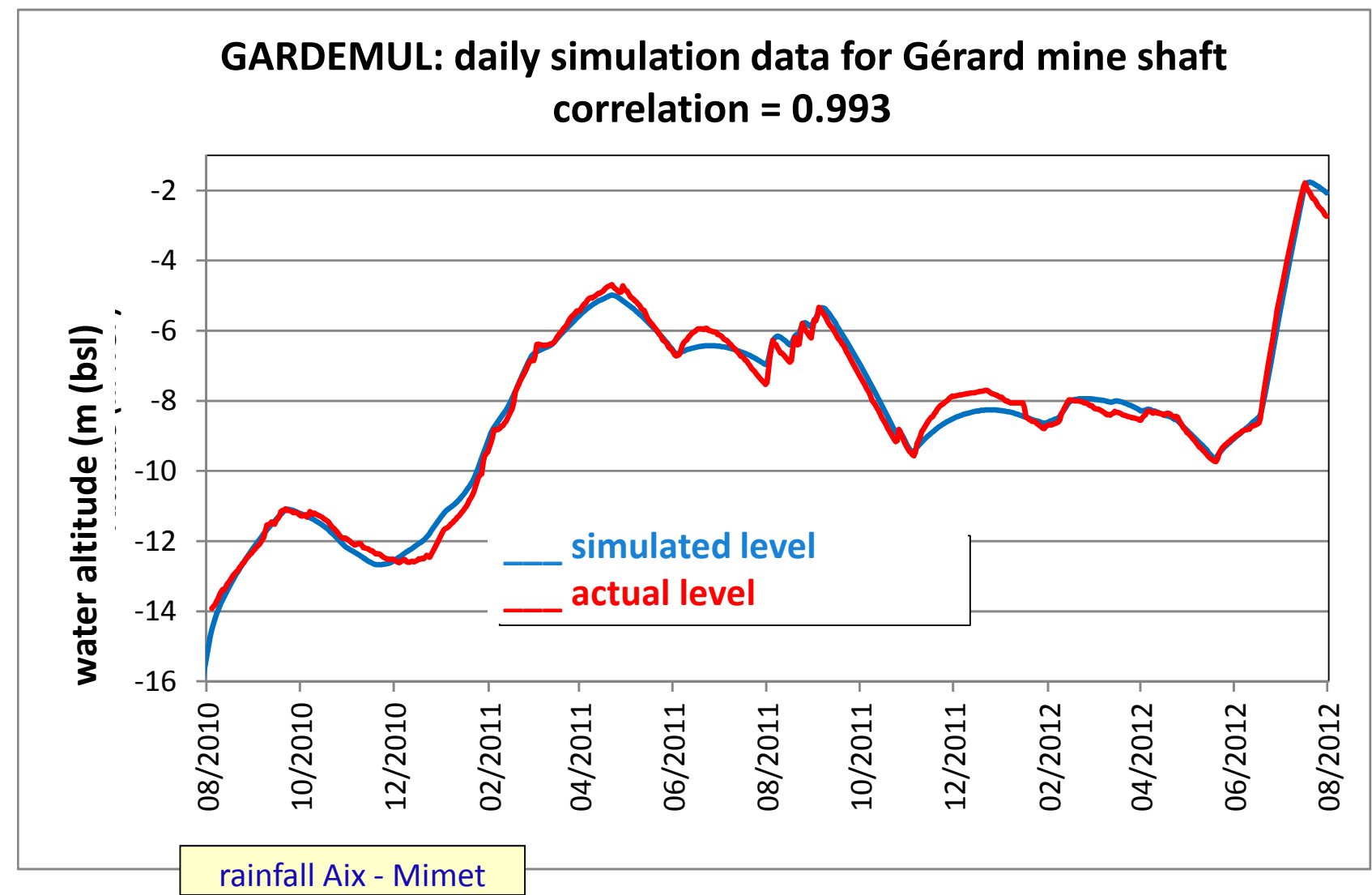

Figure 14 Simulation of the water level in the Gérard mineshaft at one-day intervals, August 2010 to July 2012

The GARDEMUL computing code is able to separate the two components (rainfall and pumping from the shaft) influencing the water level calculated for the Gérard mineshaft. 
During the August 2010 - July 2012 period, the influence of effective rainfall and dewatering is of the same order of magnitude.

For the April 2012 - July 2012 period, the increased pumping rate in April and May and the cessation of pumping from the end of June to mid-July are clearly in evidence.

The estimations of infiltration areas range from 31 to $36 \mathrm{~km}^{2}$, for overall equivalent porosity of $0.26-0.30 \%$.

When applied to the full range of observable effective rainfall in the region, this approach makes it possible to gauge the pumping capacity that needs to be installed.

\section{Conclusions}

The hydraulic behaviour of the Gardanne mine reservoir changed after mining ceased. This may be accounted for by the presence of water stocks in the eastern part of the autochthonous mine area that are under more pressure than in the Gérard dewatering mineshaft. Together with the inflow of Jurassic waters, these appear to generate permanent water volumes at a rate of around $800 \mathrm{~m}^{3} / \mathrm{h}$ in addition to the volumes from rainwater infiltration across the Fuvelian limestone outcrops capping the lignite deposits (in the eastern part of the autochthonous mine area and the Lambeau Charrié).

This makes it essential to upgrade the pumping facilities in order to control the water level in the Gérard mineshaft and prevent mine waters from flooding into the port of Marseille.

The design of new pumping capacity called on 3D techniques that made it possible to visualise the connections between the mined areas and the influence of the geology. The inflow/outflow simulations calibrated to the water levels according to flow rates and time intervals in the first two years of dewatering produced orders of magnitude for the flow rates and separated their sources. These tools are now in routine use for monitoring and surveillance of the post-mining installations. They also allow data from the microseismic monitoring network to be cross-referenced with flooding levels in the different mine workings.

However, there is still greater scope for their use in different research fields (3D hydrogeological modelling of complex reservoirs and managing uncertainties in these models, for example) or studies for added-value uses of mining effluent in the very short term (applications involving geothermal heat pumping and reinjection into a mineshaft). Continuous upgrades of these tools will in any case ensure the availability of a robust knowledge base on the mine reservoir and its behaviour. This will facilitate and rationalise subsequent uses of the mine (e.g., as a drinking-water reserve), particularly once the mineral content becomes low enough to decommission the existing pumping installations.

\section{Acknowledgement}

We thank G. Bellenfant, G. Roger and L. Martin for their help and precious contribution to this study.

\section{References}

CESAME (Conseil en Environnement, Sols et Aménagement) (2002) Étude hydrogéologique-concessions minières de la région de Gardanne (13) - (concessions C2 à C8, C10, C13, C14, C16 et EG), Vol. 1 (texte) et 2 (Figures et Annexes), H.B.C.M., France.

Dheilly, A. (2011) Evolution des niveaux de l'eau dans le réservoir minier de Gardanne (13) après la fin de l'exploitation minière en mai 2003 et analyse de la première année de pompage (aout 2010- juillet 2011), BRGM/RP-60231-FR, Décembre, France.

Stephan-Perrey, J., Gabalda, S., Guillen, A., Courrioux, G. avec la collaboration de Dheilly, A., Ben Slimane, K., Moulin, M. et Gonzalez, G. (2011) Modélisation géologique 3D du bassin minier de Gardanne à l'échelle régionale, Rapport BRGM/RP60551-FR, France.

Thiéry, D. (2012) Modélisation globale de l'évolution des niveaux dans la mine de Gardanne de 2004 à juillet 2012, BRGM/RP 61475-FR, France. 